УДК 004.78:004.056

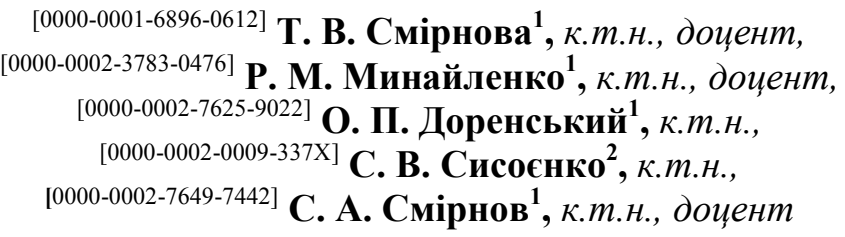

${ }^{1}$ Центральноукраїнський національний технічний університет просп. Університетський, 8, м. Кропивницький, 25006, Україна e-mail: it-kntu@ukr.net

${ }^{2}$ Черкаський державний технологічний університет б-р Шевченка, 460, м. Черкаси, 18006, Україна

\title{
ХМАРНА АВТОМАТИЗОВАНА СИСТЕМА ІНТЕЛЕКТУАЛЬНОЇ ПІДТРИМКИ ПРИЙНЯТТЯ РІШЕНЬ ДЛЯ ТЕХНОЛОГІЧНИХ ПРОЦЕСІВ
}

Прачя присвячена виріменню завдання оптимізачії технологічного процесу відновлення й змічнення поверхонь валів зі сталі шляхом реалізації методу й узагальненої моделі ланцюга абстрактних технологічних процесів у вигляді хмарної автоматизованої системи інтелектуальної підтримки прийняття рімень. Означене дає можливість розв'язати задачу побудови оптимізованого ланџюга технологічного процесу відновлення й зміџнення поверхонь валів із вибором раціонального прочесу серед альтернативних згідно з завданням. У роботі проаналізовано абстрактний технологічний процес, його властивості, методи переходу до конкретного технологічного процесу, інформаційну модель та методи ї̈ одержання, абстрактні експертні системи, формалізацію підмножини абстрактних експертних систем, рекомендаційних систем, а також розглянуто технологічні аспекти реалізації інтелектуальної підтримки прийняття рішень технологічного процесу як хмарного сервісу, перевірки відповідності реальних характеристик, властивостей, поведінки автоматизованої системи очікуваним.

Ключові слова: хмарний сервіс, експертна система, поверхня деталей, оптимізація, електродугове напилення, рекомендаційна система.

Вступ. Нині практично в усіх галузях виробництва застосовуються інформаційні технології. Зокрема активно розвиваються та впроваджуються й хмарні технології, що дає можливість підвищити ефективність виробництва, у тому числі рівень його оптимізації. Зважаючи на вкрай важливу на сьогодні проблему оптимізації технологічного процесу (наприклад відновлення та зміцнення поверхонь деталей), застосування сучасних інформаційних технологій $є$ вимогою сучасності й, очевидно, запорукою ефективності. Разом з тим, взявши до уваги широке впровадження і застосування у виробництві Інтернет-технологій, стає очевидною доцільність створення та застосування хмарних автоматизованих систем.

Аналіз останніх досліджень і публікацій [1-6] дає підстави стверджувати, що оптимізувати виробничий процес можливо із застосуванням хмарних сервісів. У праці [1] показано, що лінії відновлення поверхонь деталей функціонують в умовах гнучкої зміни параметрів виконання технологічних операцій; тобто в таких умовах, коли одні технологічні процеси відновлення й зміцнення поверхонь можуть замінюватися іншими технологіями відновлення залежно від видів пошкодження матеріалів і від вимог щодо умов експлуатації кінцевого продукту [2]. Водночас бракує відповідних автоматизованих систем для розв'язку задачі синтезу оптимізованого ланцюга технологічного процесу (ТП), систем вибору оптимального ТП [3, 4]. Разом 3 тим, для розв'язку означених науково-технічних задач недостатньо застосовуються сучасні хмарні технології. Тож постає актуальна задача оптимізації ланцюга технологічного процесу в інформаційному забезпеченні експертних систем як хмарної АC (ХАC) інтелектуальної підтримки прийняття рішень (ІППР).

Мета дослідження, виходячи із необхідності розв'язку сформульованої науковотехнічної задачі, полягає у реалізації ХАС як сервісу (SaaS) для отримання розглянутих у працях [1-2] поверхонь валів зі сталі СТ45 з заданими характеристиками на основі ком-

(C) Т. В. Смірнова, Р. М. Минайленко, О. П. Доренський, С. В. Сисоєнко, С. А. Смірнов, 2020 DOI: $10.24025 / 2306-4412.4 .2020 .223736$ 
бінації декількох технологічних процесів. Для досягнення мети дослідження варто визначити види й область застосування експертних і рекомендаційних систем для забезпечення оптимізації ланцюга технологічних процесів. Подальші завдання проблематики побудови інформаційних технологій оптимізації комбінованих технологічних процесів відновлення й зміцнення поверхонь деталей будуть поставлені за рішенням поточного завдання реалізації хмарної рекомендаційної системи як сервісу для отримання поверхонь валів зі сталі СТ45 з заданими характеристиками на основі комбінації декількох технологічних процесів.

Виклад основного матеріалу. У праці [2] розглянуто абстрактний технологічний процес, його властивості та методи переходу до конкретного технологічного процесу, інформаційну модель технологічного процесу і методи іï одержання, абстрактні експертні системи та їх складові. Тож необхідно виконати аналіз відомих експертних систем (ЕС) оптимізації технологічних процесів і привести їх до абстрактного вигляду. Пошук оптимальних рішень під час проектування технологічного процесу з кількома відновними операціями над поверхнею зношених валів має ряд особливостей. Технологічний процес повинен складатися 3 ланцюга окремих технологічних операцій, коли кожен із процесів внаслідок обставин може бути замінено на технологічний процес на іншій основі, але аналогічний за отриманим результатом. Тобто кожний етап обробки - підготовки поверхні, відновлення, механічної обробки, зміцнення поверхні - створює ланцюг технологічних операцій, де кожна операція має можливість бути виконаною кількома методиками. Для кожного з етапів обробки характерна технологічна спадковість, коли використання технологій обробки обмежується за рахунок обмеження, яке накладено попередньо використаною операцією. Проблемою $є$ часткова технологічна спадковість, коли кожні наступні операції частково перекривають кілька попередніх технологічних операцій, яка значно ускладнює повний граф можливих ланцюгів проведених операцій. У зв'язку з означеним оптимізація процесу відновлення деталей $є$ неможливою до визначення повного кола обробки $[2,3]$.

Для оптимізації технологічної операції по ланцюгу технологічного процесу використовують експертні системи зі структурою [2], a ЕС може бути семантичною, фреймовою, продукційною, нейрофреймовою. В ЕС експертом є фахівець з відповідної технологічної операції; інженер знань - фахівець, який формалізує знання експертів, відповідає за процес отримання знань і надання їх до бази знань експертної системи; база знань - множина доступних знань щодо обраної технологічної операції; система інтелектуального рішення ключовий елемент експертної системи, який на основі наявних знань і вхідних параметрів поставленого завдання надає параметри ТП 3 оптимізацією за заданими критеріями, а інтерфейс користувача відповідає за взаємодію між комп'ютерними системами й людиною.

Синтез ЕС оптимізації ТП виконується за шість етапів: 1) визначення вхідних та вихідних даних; 2) складання словника атрибутів, які властиві обраній технологічній операції; 3) виявлення об'єктів і понять; 4) виявлення зв'язків між вхідними керованими та некерованими параметрами технологічної операції; 5) визначення цілей оптимізації; 6) визначення стратегій визначення параметрів технологічної операції для досягнення поставлених оптимізаційних задач.

$\mathrm{У}$ роботі [2] наведено ілюстрацію інформаційної моделі ТП на основі відновлення поверхні електродуговим покриттям. Модель дає змогу отримати інформацію для розрахунку характеристик, які отримуються в результаті обробки. Під час побудови математичної моделі ТП зазвичай обмежуються поданням об'єкта дослідження у вигляді «чорної скриньки». Тому виникає потреба у функціональному пов'язуванні вхідних даних та певних некерованих величин до параметрів, які вимагаються від ТП. Для електродугового напилення, як і для більшості технологічних процесів, така функціональна залежність буде мати такий вигляд:

$$
\vec{Y}=f(\vec{X}, \vec{V}, \vec{Z}, \vec{R})
$$

де $\vec{X}$ - контрольовані величини процесу з обмеженнями $\mathrm{x}_{\text {mini }} \leq \mathrm{x}_{\mathrm{i}} \leq \mathrm{x}_{\text {maxi }} ; \overrightarrow{\mathrm{V}}-$ відомі й неконтрольовані величини процесу; $\vec{Z}$ невідомі й неконтрольовані величини; $\overrightarrow{\mathrm{R}}-$ випадкові величини, які впливають на процес; $\overrightarrow{\mathrm{Y}}$ - параметри, що досягаються в процесі 
технологічної обробки. Випадкова складова $є$ такою, що не контролюється. Тому в моделях часто ними нехтують, але в процесі оцінювання адекватності моделі обов'язково робиться пошук надійних інтервалів очікуваних величин з реальними результатами.

До параметрів для електродугового напилення та величин, які задають режим ТП, належать: напруга дуги $\mathrm{x}_{1}$, дистанція напилення $\mathrm{x}_{2}$, діаметр дроту $\mathrm{x}_{3}$, товщина покриття $\mathrm{x}_{4}$, тиск у камері $\mathrm{x}_{5}$, швидкість ковзання $\mathrm{x}_{6}$; ïх допустимі границі наведено у праці [2]. Багатофакторний експеримент з регресією результатів на статичний поліном дав математичну модель ТП у лення [2].

До параметрів, які необхідно отримати в результаті обробки $\overrightarrow{\mathrm{Y}}$, належать пористість $\mathrm{y}_{1}$, міцність зчеплення $\mathrm{y}_{2}$, твердість $\mathrm{y}_{3}$, зносостійкість $\mathrm{y}_{4}$.

Для інших вихідних параметрів також маємо математичні регресійні відносини або правила їх знаходження. Множина відношень $\overrightarrow{\mathrm{Y}}$ і за типом у становлять математичну модель ТП.

Побудова ЕС вимагає наявності відношень для знаходження параметрів, які оптимізуються $\mathrm{G}(\overrightarrow{\mathrm{Y}}), \mathrm{T}(\overrightarrow{\mathrm{Y}}), \mathrm{E}(\overrightarrow{\mathrm{Y}}), \ldots$. Грунтуючись на цьому, враховуючи математичну модель ТП, побудовано постійні ЕС оптимізації ТП електродугового напилення на поверхні валів 3 метою відновлення поверхонь валів електродугового напилення. Діаграму потоку інформації для реалізації ЕС оптимізації ТП зображено в [2]. Схема передбачає наявність ітераційного пошуку методом поступового поліпшення результату з початкового допустимого режиму роботи системи. Для надійнішого результату при наявності значної нелінійності такий процес можна проводити 3 кількох початкових точок.

Виконавши аналіз інформаційних потоків під час оптимізації ТП відновлення поверхонь електродуговим напиленням, отримаємо такі інформаційні одиниці [2]: 1) база знань, яка містить дані експериментів, допустимі діапазони вхідних даних, список вхідних параметрів, список вихідних (вихідних) параметрів, методи і математичне забезпечення розрахунків витрат на процес; 2) система отри- мання вимог до результатів відновлення і критерій (або критерії) оптимізації; 3) система пошуку екстремумів у багатовимірному просторі; 4) система перевірки на досягнення результату; 5) система виявлення «зацикленості» пошуку рішень у випадках недосяжності поставлених вимог; 6) система введення неконтрольованих вхідних параметрів; 7) система забезпечення інформаційного потоку між компонентами ЕС 3 урахуванням синхронізації та взаємних блокувань. Відповідно означене $\epsilon$ складовими інформаційного забезпечення функціонування ЕC.

На основі інформаційної моделі технологічної операції електродугового напилення [2] формалізуємо й узагальнимо інформаційні моделі на більшість технологічних операцій відновлення і зміцнення сталевих поверхонь.

Нехай маємо математичну модель технологічного процесу $\mathrm{k}$ відновлення поверхонь:

$$
\vec{Y}_{k}=f\left(\vec{X}_{k}, \vec{V}_{k}, \vec{Z}_{k}, \vec{R}_{k}\right)
$$

де $\overrightarrow{\mathrm{Y}}_{\mathrm{k}} \in \mathrm{Y}$ - кількісні значення підмножини характеристик поверхонь, що отримана за результатами ТП $\mathrm{k} ; \overrightarrow{\mathrm{X}}_{\mathrm{k}} \in \mathrm{X}$ - кількісні значення підмножини відомих і контрольованих параметрів окремого технологічного процесу 3 усіх доступних.

Згідно з попередніми підмножинами позначено підмножини, які відносяться до неконтрольованих та інших вхідних параметрів (1). Оскільки в загальному випадку не відома кількість даних для побудови математичної моделі технологічного процесу, то неможливо заздалегідь визначити методи її побудови. Для цього необхідно доповнити модель додатковими даними та засобами побудови математичних моделей М.

Множина застосовних методів побудови математичних моделей процесу позначатиметься $\overrightarrow{\mathrm{M}}_{\mathrm{k}} \in \mathrm{M}$ і буде залежною від наявного набору даних для побудови моделей:

$$
\overrightarrow{\mathrm{M}}_{\mathrm{k}}=\mathrm{C}\left[\mathrm{M}, \underline{\underline{\mathrm{ydef}}} \mathrm{Y}_{\mathrm{k}}, \underline{\underline{\mathrm{def}}} \mathrm{\underline { \textrm {k } }}, \underline{\underline{\underline{\operatorname{deff}}}} \mathrm{k}\right]
$$

де def визначає операцію відбору відомих значень, які будуть використані для побудови математичної моделі. 
Означене визначення вибору множини методів побудови математичної моделі спричинене тим, що при великій кількості даних можна для регресії використовувати методи на основі апроксимацій або нейронні мережі. При малому наборі даних вибір звужується до вибору між методом найменших квадратів, сплайнів або інтерполяційних операцій. Отже, операція фільтрування допустимих методів (3) $є$ необхідною, і при доповненні бази знань методи математичного моделювання можуть змінюватися. Вибір методу 3 допустимих $\mathrm{F}$ може бути покладено на людину або виконуватися автоматично за заздалегідь внесеними пріоритетами. Тобто ЕС включатиме вкладену експертну систему математичного моделювання та алгоритми пошуку максимумів і мінімумів на ній. Результатом дії такої системи є готова математична модель:

$$
\mathrm{f}:\left[\overrightarrow{\mathrm{M}}_{\mathrm{k}}, \mathrm{y}, \mathrm{x}, \mathrm{v}\right] \text {, }
$$

де $\mathrm{f}$ - функція 3 (2).

Часто ТП є складовими складних багатоетапних технологій відновлення або зміцнення поверхонь деталей. В цьому випадку поверхня під час обробки не набуває на виході значення $\mathrm{Y}_{\mathrm{k}}$, а відбувається перетворення властивостей поверхні $\overrightarrow{\mathrm{Y}}_{\mathrm{k}} \rightarrow \overrightarrow{\mathrm{Y}}_{\mathrm{k}+1}$, водночас на результат можуть впливати вхідні властивості (як при шліфуванні) або можуть і не впливати (як при електродовому напиленні). Тож для узагальненої моделі ТП модель (2) варто доповнити вхідними параметрами поверхні, яка з урахуванням (3) й (4)

$$
\overrightarrow{\mathrm{Y}}_{\mathrm{k}}=\mathrm{F}[\mathrm{C}[\mathrm{M}, \mathrm{y}, \mathrm{x}, \mathrm{v}]]\left(\overrightarrow{\mathrm{X}}_{\mathrm{k}}, \overrightarrow{\mathrm{V}}_{\mathrm{k}}, \overrightarrow{\mathrm{Z}}_{\mathrm{k}}, \overrightarrow{\mathrm{R}}_{\mathrm{k}}, \overrightarrow{\mathrm{Y}}_{\mathrm{k}-1}\right)
$$

Зазначені доповнення вимагають внесення змін [1] до діаграми руху інформації в EC.

До складу IC підтримки прийняття рішень [4] входить ЕС оптимізації металорізальних технологічних процесів (механічної обробки різанням або обробки різанням). Іїі інформаційна модель [2] містить розглянуті функції-моделі металорізального процесу (обробки різанням), розрахунки параметрів, які можна включити до оптимізації, виділені вхідні й вихідні дані. Водночас до вхідних даних відносяться вимоги до результату оброблення й обмеження на ресурси, а до вихід- них - віднесені параметри ТП і параметри отриманого виробу з витратами на його виробництво. Варто зазначити, що, якщо унікальні параметри включити до множин $\mathrm{M}, \mathrm{V}, \mathrm{X}, \mathrm{i} \mathrm{Y}$, то запис у векторній формі (5) також є узагальненням і до металорізальних ТП.

На основі математичного співвідношення (5) і діаграми потоку інформації в узагальненій ЕС ТП проведено формалізацію підмножини абстрактних ЕС оптимізації ТП. Для цього використано такі позначення множин, які формують базу знань для ряду ТП, що містить операцію виділення підмножин елементів окремої технологічної операції k: 1) $X_{k}-$ множина керованих параметрів ТП k; 2) $Y_{k}$ - множина параметрів деталі, які контролює чи змінює ТП $\mathrm{k}$; 3) $\mathrm{V}_{\mathrm{k}}$ - множина параметрів, які не управляються, але які необхідно враховувати під час виконання ТП k; 4) $\mathrm{M}_{\mathrm{k}}-$ множина методів отримання математичної моделі ТП $\mathrm{k}$; 5) $\mathrm{P}(\mathrm{m}), \mathrm{m} \subset \mathrm{P}\left(\mathrm{M}_{\mathrm{k}}\right)$ - обраний екземпляр з методів оптимізації, який можна застосувати для зазначених математичних моделей, $\mathrm{R}$ - операція вибору методу 3 множини методів (операція вибору може проводитися автоматично або за вибором розробника EC); 6) $\mathrm{D}_{\mathrm{k}}$ - множина функцій розрахунку матеріальних (зокрема й часових) витрат на виконання ТП $\mathrm{k}$, за якими може проводитися процес оптимізації (до неї належать і лінійні або більш складні комбінації для отримання остаточної багатофакторної вагової оптимізаційної функції); 7) $\mathrm{G}_{\mathrm{k}}$ - множина матеріальних ресурсів, які використовує ТП. Знаком вектора на позначеннях визначаємо конкретний кортеж реальних величин, які відповідають множині обраних величин і характеристик. Тоді 3 діаграми потоку інформації в реалізації узагальненої k-ї ЕС оптимізації ТП [2] випливають такі співвідношення для окремого ТП k:

$$
\left\{\begin{array}{l}
\overrightarrow{\mathrm{X}}_{\mathrm{k}}=\mathrm{m}\left(\overrightarrow{\mathrm{Y}}_{\mathrm{k}}, \overrightarrow{\mathrm{V}}_{\mathrm{k}}, \overrightarrow{\mathrm{Y}}_{\mathrm{k}-1,}, \overrightarrow{\mathrm{G}}_{\mathrm{k}}\right) \\
\overrightarrow{\mathrm{G}}_{\mathrm{k}}=\mathrm{D}_{\mathrm{k}}\left(\overrightarrow{\mathrm{X}}_{\mathrm{k}}, \overrightarrow{\mathrm{V}}_{\mathrm{k}}\right) \\
\left|\overrightarrow{\mathrm{G}}_{\mathrm{k}}\right| \rightarrow \min \\
\left|\overrightarrow{\mathrm{G}}_{\mathrm{k}}\right|=\infty, \quad \overrightarrow{\mathrm{Y}}_{\mathrm{k}-1} \notin \mathrm{Y}_{\mathrm{k}}
\end{array}\right.
$$

(C) Т. В. Смірнова, Р. М. Минайленко, О. П. Доренський, С. В. Сисоєнко, С. А. Смірнов, 2020 DOI: $10.24025 / 2306-4412.4 .2020 .223736$ 
У (8) значення нормування має ширше значення, яке набуває змісту виділення скаляра 3 вектора матеріальних витрат. Метод виділення скаляра може значно різнитися залежно від обраного ТП, проте в більшості випадків за цю операцію можна прийняти лінійну комбінацію матеріальних і часових витрат. За потреби досягнення максимальності одного 3 показників пропонується в лінійній комбінації використовувати негативні коефіцієнти. Крім того, складність у пошуку оптимального режиму обробки полягає в тому, що система (6) містить як аргументи i результати одні й ті ж множини числових значень. Водночас операції m i $\mathrm{D}_{\mathrm{k}}$ можуть мати нелінійний характер, ділянки запізнення або не будуть виражатися аналітично, коли процеси розрахунку можуть виконуватися декларативно, або будуть результатом імітаційного моделювання. Також для застосування деяких алгоритмів оптимізації проведено доповнення $\left|\overrightarrow{\mathrm{G}}_{\mathrm{k}}\right| \rightarrow \infty, \overrightarrow{\mathrm{Y}}_{\mathrm{k}-1} \notin \mathrm{Y}_{\mathrm{k}}$, яке вступає в силу, коли надходить неможлива вимога до ТП, і повертає значно перевищену потребу в ресурсах. Тим самим будь-який процес стає придатним для використання, але його використання приймається за неефективне. Таке введення дає змогу включити до алгоритмів оптимізації додатково велику базу пошукових евристик. Також аналітичне доповнення розрахунків використаних ресурсів швидким зростанням ресурсних потреб при виході за вхідні вимоги технологічного процесу розширює методики оптимізації градієнтними спусками.

Сукупність S і вираз (6) формують формальну задачу множини ТП. Додавання до бази знань нового ТП супроводжується такими операціями:

$$
\left\{\mathrm{S}=\mathrm{S} \cup \mathrm{S}_{\mathrm{k}}, \mathrm{S}_{\mathrm{k}}=\left\langle\mathrm{X}_{\mathrm{k}}, \mathrm{Y}_{\mathrm{k}}, \mathrm{V}_{\mathrm{k}}, \mathrm{M}_{\mathrm{k}}, \mathrm{P}_{\mathrm{k}}, \mathrm{D}_{\mathrm{k}}, \mathrm{G}_{\mathrm{k}}\right\rangle,\right.
$$

де $\mathrm{k}$ є номером доданого до системи ТП.

Наступним етапом дослідження є формалізація рекомендаційних систем (РС) для забезпечення оптимізації ланцюга ТП як надбудови ЕС над експертними системами окремих ТП. Як відомо, виготовлення продукції вимагає використання послідовності ТП [2]. Кожен із ТП відповідно до позначень приймає деталь 3 параметрами $\overrightarrow{\mathrm{Y}}_{\mathrm{k}-1}$ і повертає $\dddot{1}$ п па- раметрами $\overrightarrow{\mathrm{Y}}_{\mathrm{k}}$. Це формує ланцюг технологічних операцій (10):

$$
\mathrm{Y}=\sum_{\mathrm{k})} \overrightarrow{\mathrm{Y}}_{\mathrm{k}}
$$

де $\langle\mathrm{k}\rangle$ - екземпляр комбінаторної конфігурації з доступних ТП, а k-1 - попередній ТП.

Таким чином, сукупність відношень (6), (7), (8), дію яких представлено графами [2], формують узагальнену модель ланцюга абстрактних ТП.

Реалізація хмарної автоматизованої системи інтелектуальної підтримки прийняття рішень ТП пропонується на основі результатів роботи [7]. Виконаний у ній аналіз моделей обслуговування хмарних сервісів показав, що основними, які призначені для вирішення різних інженерних задач, розрахунків, аналізу й створення моделей фізичних процесів, $\epsilon$ PaaS i SaaS [10]. PaaS підходить для ефективного надання програмних середовищ та інструментів для розробників промисловим організаціям, які розробляють і тестують програмне забезпечення та застосунки для баз даних. Це забезпечує повне та централізоване середовище розвитку, яке доступне на вимогу. При правильній реалізації $\mathrm{SaaS}$ може забезпечити значне заощадження коштів від традиційного підходу до володіння програмним забезпеченням. Ця модель хмарної послуги пропонує мінімізовані витрати на налаштування устаткування та програмного забезпечення, навіть якщо вона забезпечує надмірність і високу доступність, що дає змогу обслуговувати запущені програми. Кінцеві користувачі звільняються від управління та контролю базової ІТ-інфраструктури. Ліцензії на безпеку, мережу, обчислення та всі ліцензії на програмне забезпечення вкладаються в щомісячну або щорічну плату, виключаючи або значно скорочуючи капітальні витрати. Натомість існує разова вартість доступу до будьяких бажаних послуг. Організації платять за те, що вони використовують, і часто мають можливість додавати або видаляти послуги за потребою.

Деякі середовища, що базуються на хмарі, включають складні середовища моделювання для повного тестування проектних застосунків перед переміщенням їх у виробничу систему. Програми й застосунки для баз даних можуть бути спеціальним програмним 
забезпеченням, які промислові організації раніше використовували, але зараз розгортаються на віртуальних машинах у хмарі. Вони також можуть бути додатками, побудованими в хмарі за допомогою платформи й інструментів, наданих постачальником послуг автоматизації. У деяких випадках та сама програмна система може використовуватися для програм SaaS i PaaS. Інженери з управління та процесів можуть використовувати модель $\mathrm{Pa} S$ для розробки програми та $\mathrm{SaaS}$ для їх виробничого середовища. Наприклад, автоматизація, керування процесами та програмне забезпечення SCADA, що традиційно пропонується лише на базі замовника, доступні як позапроцесорне середовище розробки та моделювання (Open VEP) або як програмне забезпечення SCADA, оптимізоване для забезпечення надійності та безпеки для моніторингу на рівні підприємства i контролю розповсюджених активів [10].

Розміщення такої програмної системи в центрі обробки даних з прямим високошвидкісним підключенням до телекомунікацій та Інтернету дає можливість швидкодіючого й надійного підключення до всіх віддалених пристроїв, візуалізації загального процесу. В рамках цих сервісів з'являється досить новий перспективний сервіс CAEaaS - комп'ютерні системи інженерного аналізу як сервіс, призначений для перенесення роботи систем інженерних розрахунків та систем автоматизованого проектування на хмарну платформу. Разом 3 тим, CAE (Computer-Aided Engineering) використовується для опису процедури всього процесу інженерії продукту, від проектування та віртуального тестування за допомогою складних аналітичних алгоритмів до планування виготовлення. САЕ $є$ наступним кроком не тільки розробки продукту, але й підтримки інженерного процесу, оскільки він дає змогу виконувати випробування та моделювання фізичних властивостей виробу без необхідності фізичного прототипу [11].

У праці [19] наведено характеристики сервісів IaaS, PaaS, HaaS, SaaS, CAEaaS. Відповідно IaaS надає сервіс онлайнового зберігання, синхронізації файлів, віртуальних машин і провайдерується Dropbox, Google Drive, Amazon; PaaS забезпечує розвиток і розміщення мережевих застосунків, систему запиту бази даних для аналізу великих наборів даних, розвиток інтерфейсів користувача і соціальних мережевих сайтів на базі Microsoft Windows Azure, Salesforce.com, Amazon, мережевих сайтів: HaaS - постачання пошукових систем, Ponoko, shapeways, MFG.com, Quickpats.com; $\mathrm{SaaS}$ - високопродуктивні обчислення у хмарі, $\mathrm{CAD}$, надання хмари, 3D-моделювання, мобільний оглядач на Autodesk360-платформі, Dassault Systemes, Sabalcore; CAEaaS універсальна програмна система кінцевоелементного аналізу (ANSYS), система для проектування й розрахунку в галузі машинобудування (WinMachine).

Відповідно до [11] переваги PaaS полягають, насамперед, у такому: 1) він дає можливість програмувати більш високий рівень із різко зниженою складністю; 2) загальна розробка застосунку може бути ефективнішою, оскільки зменшуються ресурси інфраструктури і технічне обслуговування, вдосконалення програми, таким чином, стає простішим. Водночас до недоліків різних постачальників $\mathrm{PaaS}$, на які посилаються користувачі, можна віднести відсутність функціональних можливостей, зниження контролю, труднощі систем маршрутизації трафіку.

Обговорення результатів дослідження. $\mathrm{PaaS}$ забезпечує зовнішню мережеву підтримку, яка доповнюється IT-інфраструктурою, обчислювальними ресурсами, виробничим технічним забезпеченням, прикладним програмним забезпеченням завдяки сервісам IaaS, HaaS i SaaS. ANSYS має власні активи в хмарі і щорічно оновлюється, не вимагаючи перевстановлення ключів. Доцільним для застосування для досягнення мети роботи $\epsilon$ хмарний сервіс CAEaaS. Biн допомагає скоротити витрати i час на розробку продукту, покращити якість і довговічність продукту. Комплексне керування даними САE та управління процесами розширює здатність ефективно використовувати уявлення про ефективність та вдосконалювати конструкції для широкої спільноти [7]. Очевидно, надалі постане задача перевірки відповідності реальних характеристик, властивостей, поведінки ХАС ІППР очікуваним, розв'язок якої забезпечить застосування методики [8].

Висновки й перспективи подальшого розвитку. В роботі запропоновано хмарну автоматизовану систему інтелектуальної підтримки прийняття рішень технологічних процесів як реалізацію методу оптимізації ТП відновлення й зміцнення поверхні валів

(C) Т. В. Смірнова, Р. М. Минайленко, О. П. Доренський, С. В. Сисоєнко, С. А. Смірнов, 2020 DOI: $10.24025 / 2306-4412.4 .2020 .223736$ 
зі сталі. У дослідженні розглянуто абстрактний ТП, його властивості й методи переходу до конкретного технологічного процесу, інформаційну модель ТП, методи іiі одержання, абстрактні EC, на основі чого запропоновано формалізацію підмножини абстрактних ЕС оптимізації ТП, формалізацію рекомендаційних систем для забезпечення оптимізації ланцюга ТП як надбудови ЕС над експертними системами окремих технологічних процесів.

Хмарна АC інтелектуальної підтримки прийняття рішень технологічних процесів, яка реалізує метод оптимізації ТП відновлення й зміцнення поверхонь валів зі сталі, забезпечує розв'язок задачі побудови оптимізованого ланцюга ТП відновлення й зміцнення поверхонь валів із вибором найбільш раціонального процесу серед альтернативних згідно 3 завданням.

\section{Список використаних джерел}

[1] Т. В. Смірнова, Є. К. Солових, О. А. Смірнов, та О. М. Дрєєв, "Побудова хмарних інформаційних технологій оптимізації технологічного процесу відновлення та зміцнення поверхонь деталей", Центральноукраӥнський науковий вісник, вип. 1 (32), c. 184-194., 2019.

[2] А. А. Смирнов, Т. В. Смирнова, А. Н. Дреев, и А. В. Дудан, "Оптимизация технологического процесса восстановления и упрочнения поверхностей с заданными характеристиками в виде облачного сервиса", Вестник Полочкого государственного университета, № 3, с. 50-61, 2020.

[3] К. І. Скрипка, та М. А. Зенкин, "Експертна система автоматизованого вибору способів відновлення спрацьованих деталей", Вісник ЖДТУ, № 1 (28), с. 66-68, 2004.

[4] В. В. Лимаренко, "Інформаційна система підтримки рішень для автоматизації створення технологічних процесів механообробки деталей високоточного обладнання", дис.. канд. техн. наук, Нац. техн. ун-т "ХПІ", Харків, 2019.

[5] К. К. Бабич, А. И. Секирин, и Д. Д. Новиков, "Подсистема оптимизации работы гибких производственных систем с использованием многокритериальных генетических алгоритмов", Інформатика $i$ кібернетика, № 3 (9), с. 24-28, 2017.
[6] N. Nidhiry, and R. Saravanan, "Scheduling optimization of a flexible manufacturing system using a modified NSGA-II algorithm", Advances in Production Engineering \& Management, vol. 9, no. 3, pp. 139-151, 2014.

[7] Т. В. Смірнова, Л. І. Поліщук, О. А. Смірнов, К. О. Буравченко, та А. О. Макевнін, "Дослідження хмарних технологій як сервісів", Кібербезпека: освіта, наука, техніка, т. 3, вип. 7, с. 43-62, 2020.

[8] О. М. Верес, Технологї підтримання прийняття рішень. Львів: Вид-во Львів. політехніки, 2013.

[9] Worldwide Public Cloud Services Spending Will More Than Double by 2023. USA, Framingham, July 3, 2019. [Online]. Available: https://www.idc.com/ getdoc.jsp?containerId=prUS45340719. Дата звернення: Серп. 27, 2020.

[10] Alibaba Cloud EHPC Empowers New Manufacturing-SAIC Simulation Computing Cloud (SSCC), Sept. 13, 2018. [Online]. Available: https://www.alibabacloud.com/ blog/alibaba-cloud-ehpc-empowers-newmanufacturing-saic-simulation-computingcloud-sscc_593994. Дата звернення: Серп. 27, 2020.

[11] Т. В. Смірнова, О. М. Дрєєв, та О. А. Смірнов, "Експертна система оптимізації процесу відновлення та зміцнення поверхонь деталей типу "ВАЛ" електродуговим напиленням", Системи управління, навігащіï та зв'язку, вип. 2, с. 149154, 2019.

[12] ANSYS [Електронний ресурс]. Режим доступу: http://znaimo.com.ua/ANSYS. Дата звернення: Серп. 27, 2020.

[13] САЕ-система [Электронный ресурс]. Режим доступа: http://sewiki.ru/CAEсистема. Дата звернення: Серп. 27, 2020.

[14] О. П. Доренський, "Інформаційна модель вибору методології управління життєвим циклом програмного забезпечення інфотелекомунікаційних систем", у Сучасні інформаиійно-телекомунікаційні технолоziï. Київ, Україна: ДУТ, 2015, с. 114-116.

[15] O. P. Dorenskyi, "The methodology of evaluating the test cases quality for simple IT monoprojects software testing", на $C y$ часні проблеми $і$ досягнення в галузі ра- 
діотехніки, телекомунікацій та інформаційних технологій, Запоріжжя: ЗНТУ, 2016, с. 111-112.

\section{References}

[1] T. V. Smirnova, O. A. Smirnov, and

E. K. Solovykh, "Construction technologies for optimization of the technological process of restoration and strengthening of parts' surfaces", Tsentralnoukrainskyi naukovyi visnyk, vol. 1 (32), pp. 184-194, 2019. [in Ukrainian].

[2] A. A. Smirnov, T. V. Smirnova, A. N. Dreev, and A. V. Dudan, "Optimization of the technological process of restoration and hardening of surfaces with given characteristics in the form of a cloud service", Vestnik Polotskogo gosudarstvennogo universiteta, no. 3, pp. 50-61 2020. [in Russian].

[3] K. I. Skrypka, and M. A. Zenkin, "Expert system of automated selection of methods for restoration of worked parts", Visnyk ZhDTU, № 1 (28), pp. 66-68, 2004. [in Ukrainian].

[4] V. V. Limarenko, "Information system of decision support for automation of creation of technological processes of mechanical processing of details of high-precision equipment", Ph.D. thesis, Nat. Tech. Univ. "KhPI", Kharkiv, 2019. [in Ukrainian].

[5] K. K. Babich, A. I. Sekirin, and D. D. Novikov, "Subsystem for optimizing the operation of flexible production systems using multi-criteria genetic algorithms", Informatyka i kibernetyka, no. 3 (9), pp. 2428, 2017. [in Russian].

[6] N. Nidhiry, and R. Saravanan, "Scheduling optimization of a flexible manufacturing system using a modified NSGA-II algorithm", Advances in Production Engineering \& Management, vol. 9, no. 3, pp. 139-151, 2014.

[7] T. V. Smirnova, L. I. Polishchuk, O. A. Smirnov, K. O. Buravchenko, and A. O. Makevnin, "Research of cloud technologies as services", Kiberbezpeka: osvita, nauka, tekhnika, vol. 3, iss. 7, pp. 4362, 2020. [in Ukrainian].

[8] O. M. Veres, Decision Support Technologies. Lviv, Ukraine: Vyd-vo Lviv. politekhniky, 2013. [in Ukrainian]

[9] Worldwide Public Cloud Services Spending Will More Than Double by 2023. USA, Framingham, July 3, 2019. [Online]. Available: https://www.idc.com/ getdoc.jsp? containerId=prUS45340719. Accessed on: Aug. 27, 2020.

[10] Alibaba Cloud EHPC Empowers New Manufacturing - SAIC Simulation Computing Cloud (SSCC), Sept. 13, 2018. [Online]. Available: https://www.alibabacloud.com/ blog/alibaba-cloud-ehpc-empowers-newmanufacturing-saic-simulation-computingcloud-sscc_593994. Accessed on: Aug. 27, 2020

[11] T. V. Smirnova, O. M. Dreev, and O. A. Smirnov, "Expert system for optimization of the process of restoration and strengthening of surfaces of parts of "VAL" type by electric arc spraying", Systemy upravlinnia, navihatsii ta zviazku, iss. 2, pp. 149-154, 2019. [in Ukrainian].

[12] ANSYS. [Online]. Available: http://znaimo.com.ua/ANSYS. Accessed on: Aug. 27, 2020.

[13] CAE-system. [Online]. Available: http://sewiki.ru/CAE-system. Accessed on: Aug. 27, 2020.

[14] O. P. Dorenskyi, "Information model of the choice of methodology of life cycle management of infotelecommunication systems software", in Modern informationtelecommunication technologies. Kyiv, Ukraine: DUT, 2015, pp. 114-116. [in Ukrainian].

[15] O. P. Dorenskyi, "The methodology of evaluating the test cases quality for simple IT monoprojects software testing", in Modern problems and achievements in the field of radio engineering, telecommunications and information technologies, Zaporizhzhya: ZNTU, 2016, p. 111-112. 
T. V.Smirnova ${ }^{1}$, Ph.D., accociate professor,

R. M. Mynailenko ${ }^{1}$, Ph.D., accociate professor,

O. P. Dorenskyi ${ }^{1}, P h . D$.,

S. V. Sysoienko ${ }^{2}, P h D$.,

S. A. Smirnov ${ }^{1}$, Ph.D., accociate professor

${ }^{1}$ Central Ukrainian National Technical University

Universytetskyi ave. 8, Kropyvnytskyi, 25006, Ukraine

e-mail: it-kntu@ukr.net

${ }^{2}$ Cherkasy State Technological University

Shevchenko blvd, 460, Cherkasy, 18006, Ukraine

\section{CLOUD AUTOMATED SYSTEM OF INTELLECTUAL SUPPORT OF DECISION-MAKING FOR TECHNOLOGICAL PROCESSES}

Today there is a very important problem of optimization of technological processes, for example, the technological process of restoring and strengthening the surfaces of parts. This problem can be solved by using modern information technology. This will optimize technological processes effectively. At the same time, Internet technologies and cloud services are now being actively implemented and used in production. Therefore, the expediency of creating and using cloud automated systems is obvious.

The article is devoted to the cloud automated system of intellectual support of decision-making for technological processes. The basis of the system is the implementation of the method of optimization of the technological process of restoration and strengthening of the surface of steel shafts. The research considers the abstract technological process, the properties of the abstract technological process, methods of transition to a specific technological process, the information model of the technological process, methods of obtaining an information model, abstract expert systems. The formalization of a subset of abstract expert systems of technological process optimization, the formalization of recommendation systems to ensure the optimization of the technological process chain as a superstructure of the expert system over the expert systems of individual technological processes is proposed. Also a cloud automated system as a service (SaaS) for obtaining the surfaces of ST45 steel shafts with specified characteristics based on a combination of several technological processes is described. To achieve the goal of the study, the types and scope of expert and recommendation systems to ensure the optimization of the chain of technological processes are identified. Tasks of construction of information technologies of optimization of combined technological processes of restoration and strengthening of surfaces of details will be set by the decision of current task of realization of the cloud recommendation system as a service for receiving the surfaces of shafts from steel with the set characteristics on the basis of a combination of several technological processes.

The cloud automated system of intellectual decision support of technological processes implements the method of optimization of technological process of restoration and strengthening of a surface of shafts from steel, provides a solution of a problem of construction of the optimized chain of technological process of restoration and strengthening of surfaces of shafts.

Keywords: cloud service, expert system, surface of details, optimization, electric arc spraying, recommendation system.

Стаття надійшла 16.11.2020

Прийнято17.12.2020

(C) Т. В. Смірнова, Р. М. Минайленко, О. П. Доренський, С. В. Сисоєнко, С. А. Смірнов, 2020 DOI: $10.24025 / 2306-4412.4 .2020 .223736$ 